\title{
A Study on Metacognitive Strategy Use in Listening Comprehension by Vocational College Students
}

\author{
Zhaowen $\mathrm{Cao}^{1} \&$ Yuewu $\mathrm{Lin}^{2}$ \\ ${ }^{1}$ Foreign Languages College (International Education College), Jiangxi University of Technology, China \\ ${ }^{2}$ Foreign Languages College, Jiangxi Normal University, China \\ Correspondence: Yuewu Lin, Foreign Languages College, Jiangxi Normal University, Yaohu Campus, 99 Ziyang \\ road, Nanchang, Jiangxi, 330022, China.
}

Received: March 1, 2020

Accepted: March 27, 2020

Online Published: March 28, 2020

doi: 10.5539/elt.v13n4p127

URL: https://doi.org/10.5539/elt.v13n4p127

Project Sources: This thesis is the periodical results on the Educational Reform Subject of Jiangxi Provincial Department of Education-- Exploration and Practice of English Listening Teaching Based on Krashen's Second Language Acquisition Theory No. JXJG-17-24-9

\begin{abstract}
Metacognitive strategies concerning general skills, through which learners manage, direct, regulate and guide their learning. For several decades, researchers have recognized the importance of Metacognitive strategy use for successful English listening comprehension. Most of the previous studies of metacognitive strategies use in China have been carried out among undergraduates, but few focus on that of vocational college students. Therefore, it is necessary to carry out investigation into metacognitive strategies use in English listening comprehension among vocational college students so as to give vocational college English teachers pedagogical implications on how to train their students and facilitate their teaching. The aim of the present study is to make a tentative investigation into the metacognitive strategies use in the listening comprehension among vocational college students. The subjects in the present study consist of one hundred and thirty nine vocational college students in the Jiangxi Blue Sky College. And three instruments were involved in the present study. They are questionnaire, listening comprehension test and interviews. The present research has yielded the following findings: 1. Based upon the results, the frequency of students' metacognitive strategy use frequency is relatively low, and there is a rather large discrepancy among students ' use of metacognitive strategies in listening. 2 . The analysis shows that females employ metacognitive strategies more often than males' students. There is significant difference in the use of planning strategies, monitoring strategies, self-evaluation strategies and self-regulation strategies, and the most significant difference is shown in monitoring strategies.3. From the results, it is found that the higher score the students get, the more frequently they use the strategies. Especially to the monitoring strategies, there is significant difference between the high score and low score students.4. With regard to the relationship between the employment of metacognitive listening strategies and listening comprehension ability, analysis shows that there is a positive relationship between metacognitive strategies and listening comprehension ability. The more frequently they apply the metacognitive listening strategies, the stronger their listening comprehension ability will be.
\end{abstract}

Keywords: metacognitive strategies, listening comprehension, vocational college students

\section{Introduction}

With the wide spread of English as a world language, people gradually realized the important role of the mastery of English. Of the four basic skills in English, listening seems to be the primary means by which all incoming ideas and information are taken in. River and Temperly (1984) pointed out that listening takes up $45 \%$ in the language communication activities, while speaking is $30 \%$, reading $16 \%$ and writing $9 \%$. In other words, listening is a vital information input. There is no language acquisition without language input (Krashen, 1985). Without properly understandable input, it is impossible to begin any learning.

In vocational college, more and more attention is being paid to language application. Therefore, listening and speaking have weighed more and more in English teaching and learning. Many students spend lots of time to 
listen to the tapes and radio programs after class to improve their listening comprehension. However, listening comprehension still remains a big problem for most of vocational college students. According to some relevant materials, lacking of right methodology is one of the major reasons leading to their failure of listening comprehension. Generally, it is widely accepted that students will pick up listening comprehension skills rather than being taught explicitly. In a listening class, we often find that the teacher just stands beside the machine to press the button of "play" or "pause" without giving students any advice on how to listen and comprehend intelligently. Obviously, it is hard to improve students' listening comprehension level. Teaching student to handle listening tasks by using series of strategies will lead to better comprehension. A strategy-based approach is adopted to integrate strategy instruction into listening lessons, and the aim is to direct student toward efficient use of listening strategies.

\section{Literature Review}

\subsection{Definition of Listening Comprehension}

Listening is difficult to describe for it is an invisible mental process. As early as 1970, Asher started to study the role of listening which is used as a tool for understanding and a main factor in facilitating language learning. From then on, listening has been playing an important role in the process of second language acquisition.

According to Barker (1971), the definition of listening is "hearing, attention, understanding, and remembering", definitely including cognitive and behavioral events. Barker and Watson (1984) defined listening from four aspects: Sensing, which refers to taking in messages verbally and nonverbally; Interpreting, which refers to the process of understanding; Evaluating, involves sorting fact from opinion and agreeing or disagreeing with the speaker; Responding, which refers to the use of verbal and nonverbal cues in reaction to a message. Brown (1993) gave both narrow and broad definitions to listening. The narrow definition of listening is the process by which listeners come to interpretation for a stream of speech. And the broad definition of listening also includes the process by which listeners use those interpretations for their intended purpose.

Listening comprehension is a relative passive activity. The listener must discriminate between sounds, understand vocabulary and grammatical structures in Listening comprehension, interpret stress and intonation, retain what was gathered in all of the above, and interpret it immediately within the social-cultural context of the utterance. Rost (2002) defines listening, in it's broadest sense, as a process of receiving what the speaker actually says (receptive orientation); constructing and representing meaning(constructive orientation); negotiating meaning with the speaker and responding(collaborative orientation);and, creating meaning through involvement, imagination and empathy(transformative orientation).Listening is a complex, active process of interpretation in which listeners match what they hear with what they already know.

\subsection{Definition of Meta-Cognitive Strategies}

Metacognitive strategies made up of a series of skills used with particular metacognitive knowledge in mind. Therefore, metacognitive strategies include an ability of consciously using metacognitive knowledge to plan for, arrange, monitor, regulate and evaluate the learning process and learning situation and respond accordingly. Although different researcher may use different words to describe metacognitive strategies, but the above strategies almost involve all definitions they mentioned. Through the classification schemes offered by previous researchers, there is a conclusion that metacognitive strategies cover five parts: self-awareness, self-planning, self-monitoring, self-regulation and self-evaluation.

Self-awareness refers to consciously identifying what one already knows, establishing one's objectives, determining one's motivation and anxiety level, and considering task requirements. For example, learners must be aware of the purposes of their English learning: to expand their vocabulary to improve reading comprehension or to improve their listening and speaking ability.

Self-planning indicates the selection of appropriate strategies and the allocation of resources that effect performance. Before beginning a task, learners must make predictions before listening, arrange strategies in order, and allocate time reasonable. Learners must consider what learning resources are available. They must also estimate time required to complete tasks, make time schedule, and set priorities. Planning decisions (as cited in Wenden, 1987) include determining: whether they can perform the task; how much of the given task they can expect to complete; which parts of the task will be easiest and why; which will be the difficult and why; whether or not it is necessary to engage in deliberate learning; and which will be the most efficient strategies for completing the task.

Self-monitoring refers to learners' online awareness of comprehension and task performance when the task is taking place. According to O'Malley and Chamot (1990), as a learner, the basic self-monitoring skill is checking, 
verifying or correcting his/her comprehension or performance in the course of a language task. This skill let the learners know what they understand and what they misunderstand. Brown (1978) argues that ability develops slowly and quite poor in children and even adults. However, this skill can tell the good language learners from the poor language learners. The more complex of tasks are, the more difficult in monitoring the mind is to finish tasks. Moreover, learners have to concentrate on the task in order to enhance successful accomplishment of it.

Self-regulation refers to regulating learning plans and strategies when learners come across comprehension problems and slow down their understanding. Learners adjust their strategies according to the effectiveness of previous strategies. Some researchers (Paris and Winograd, 1990) equal self-regulation to self-management, which helps learners to modify "their thinking processes in order to cope with changing situational demands" (Kelly, 1991).

Self-evaluation refers to checking outcomes, or evaluating the achievements and efficiency of one's learning. Classical examples include revaluating one's goals and conclusions. The decisions learners have to make are as follow: whether the production of their learning is contradictory to or consistent with other parts of a text or available material (ability to see similarities and differences and appreciate what it means); whether the production is consistent with reality or common sense (understanding of the relationship with learning and reality, i.e., the purpose of learning, personal goals, etc.); and whether they have been able to apply the rules they know and how well.

In conclusion, a metacognitive strategy is like a tactic used by a player on the playground. That is to say, if a football player wants to succeed in a match, he not only has to possess a range of skills, like keeping the ball by himself, passing the ball to another player, receiving the ball from others and finally shoot the ball; but also has to be aware of other things that are going around him, to choose the appropriate skills and strategies for the particular moment, and to monitor whether his determination is appropriate or not. All these mentioned refer to what researchers call "metacognitive strategies" in language learning.

\subsection{Review of Studies on Listening Comprehension and Metacognitive Strategy Use}

O'Malley and Chamot (1990) conduct a study to probe the approaches in which individual strategies are used by English as the second language students from Spanish-speaking countries on a listening comprehension task. In order to evaluate students' reported self-perception of their listening comprehension strategies, Vogely (1995) has designed a strategy questionnaire. It focused on the learners' strategies and perceptions that theory has shown to be important in relation to comprehension. Wenden (1998) addresses that it is of vital importance to use metacognitive knowledge for successful listening comprehension to develop their self-regulated learning. To summarize, the weaker learners have benefited most from such a process-based approach to listening instruction.

In China there are few researches on metacognitive strategies in listening comprehension. Kong Wen (2002) wrote an article about discrete method to applicant meta-cognitive strategies in listening class, there are three approaches as follow: 1)planning, previewing, reading background knowledge before class; 2)listening for general idea, then details and the whole, and dictation practice in class; 3)making a summary of the materials, monitoring and evaluating. In fact she presented some specific ways for meta-cognitive teaching model. Hou (2004) conduct a study about metacognitive strategies on listening comprehension of English major students. A conclusion has been made that listening teaching and learning can be improved if metacognitive strategy training is incorporated into teaching and it is possible to develop learner's autonomy in learning.

\section{Methodology}

\subsection{Research Questions}

The aim of the present study is to make a tentative investigation into the metacognitive strategies which are used in the listening comprehension among vocational college students.

The four research questions of the present study are addressed as follows:

1. What is the general situation of metacognitive strategy use in listening by vocational college students?

2. Are there any differences in metacognitive strategies use between males and females in listening?

3. Are there any differences in metacognitive strategies use between high score and low score students in listening?

4. Is the employment of metacognitive listening strategies related to better comprehension? 


\subsection{Subjects}

The subjects in the present study consist of one hundred and thirty nine vocational college students from Jiangxi Blue Sky College. Among them, seventy three are female students, and the rest are male students. They are between 17 and 23 years old and their average age is 19.8. They were recruited into this college from all around China in the fall of 2018 and had completed two semesters of academic study. Before going to college, they had received an average of 6.5 years of English learning. All the subjects are native speakers of Chinese.

\subsection{Instruments}

Three instruments were involved in the present study, questionnaire, listening comprehension test and interviews.

\subsubsection{Metacognitive Listening Strategy Questionnaire}

The questionnaire is mainly based on O'Mally \& Chamot (2001)'s studies .Few statements selected from WenQiufang (1996), Vandergrift (1999), and minor modification is made in this thesis. WenQiufang's SILL (strategy Inventory for Language Learning) consists of 20 metacognitive listening strategies. Vandergrift's metacognitive listening comprehension strategies covering 35 separate strategies in four categories. O'Mally\&Chamot put forward an inventory of metacognitive tactics in learner listening in his study. It consists of 19 strategies and classified into 3 subcategories: planning, monitoring and self-evaluation.

The questionnaire contains two parts. Part one involves learners' personal information about their name, sex, and age. Part two is a five-point Likert scale from "This statement is never or almost never true of me" to "This statement is always or almost always true of me". It includes twenty seven statements with regard to metacognitive strategies related to listening comprehension from four parts: 1) planning, from item one to item seven; 2) monitoring, from item eight to item seventeen; 3) Self-evaluation, from item eighteen to item twenty three ;4) Self-regulation, from item twenty four to item twenty seven. The questionnaire is written in Chinese so that some misunderstanding can be avoided and the reliability of the research is improved.

\subsubsection{Listening Comprehension Test}

In order to measure the subjects' listening ability, one listening comprehension test is held. The test is selected from the listening section of the national-wide PRETCO (Practical English Test for Colleges, see Appendix A). It is used to test vocational college students' language competence and performance. And they must pass that test before they get their graduation certificates. There are three sections in the listening test and students are asked to finish those three sections within 15 minutes: the first section, five recorded sentences, Students are asked to answer a question about the question and choose one correct answer out of the four answers marked A, B, C and $\mathrm{D}$; the second section, five recorded dialogues with five questions, Students are asked to answer a question about the dialogue and choose one correct answer out of the four answers marked A,B,C and D; the third section: a short passage with five words missing. Students are required to fill in the blank with correct word. And the total score for the test is 15 .

\subsubsection{Interview}

Multi-method rather than a signal method is used to identify learners' strategic repertoires, which can avoid unnecessary ambiguity and criticism. So an interview is used to get more information about the participants' metacognitive strategy use and their attitudes.

In present study, a semi-structured interview is used to avoid reminding the subjects any metacognitive strategies. The interview is used to find the differences for the using of metacognitive strategies in listening between high score students and low score students and what factors will influence the use of the metacognitive strategies. The interview is adapted from Oxford's study (1990) and Teng's (1996) revision in Chinese, and Beliefs about Language Learning Inventory questionnaire (BALL, EFL version, Horwitz, 1987). The interview questions are: 1) During the English learning process, have you met difficulties? What kind of difficulties and how did you get over it? 2) Do you often review the key points and finish the task according to your experience? 3) Do you often pay attention to the special details when you listen to the message? What are the details? 4) Which is the best way to improve your listening comprehension ability in you opinion? 5) How to practice your listening comprehension? Why? 40 students will be taken out to give an interview, among them 20 from high level students and the rest from the low level students.

\subsection{Data Collection and Analysis}

There are three steps in this present study. The first step was finished on May 24th; 2018. The subjects were given 15 minutes to complete the listening comprehension test in the listening class. The test was randomly 
selected from the national-wide PRETCO.

The subjects were required to do the metacognitive strategies questionnaire once they complete the listening comprehension test. And the data collection will be done during regular class hour with the cooperation of the students' English teachers in charge of the class. Before the students fill in the questionnaire, the nature of the study will be explained to them. They are told that there is no right or wrong answers on the questionnaire and that response has no effect their course grades, they should answer them honestly and forthrightly.

The semi-structured interview was conducted in the last step on September. 40 subjects were interviewed individually. They answered the five questions one by one and their reporters were written down on the paper.

The SPSS will be used to analyze the date. And the data is collected from three kinds of sources. They are test and questionnaire. The data is analyzed both quantitatively and qualitatively. The quantitative analysis involves several statistical procedures: 1) descriptive statistics, including means, standard deviations and variances, are computed to summarize the students' test scores and strategy items; 2) independent sample t-test is employed to identify the difference of metacognitive strategy application and listening comprehension ability between genders; 3) Pearson correlation analysis is conducted to analyze how the variables related to one another, that is, to examine the relationship between listening comprehension and metacognitive strategies.

\section{Results and Discussion of the Research}

\subsection{General Pattern}

The first research question we intended to examine in the present study is the whole situation of metacognitive strategy use in listening by vocational college students. The mean, standard deviation, minimum, maximum, and rang will be presented and discussed in this section. The overall pattern on the metacognitive strategy use is shown in table 1.

Table 1. Descriptive statistics of Metacognitive Strategies

\begin{tabular}{ccccccc}
\hline Valid & Missing & Mean & Std. Deviation & Range & Minimum & Maximum \\
\hline 139 & 0 & 68.77 & 12.537 & 63 & 37 & 100 \\
\hline
\end{tabular}

The results in Table 1 shows that the mean score of metacognitive strategy use among the 139 students is 68.77 , which is relatively low, because the total score of the metacognitive strategies questionnaire is 135 . The standard deviation is 12.537 , which means that there is a big difference among each learner's metacognitive strategies use frequency. The highest score achieved 100 and the lowest score is only 37 .The range is 63 . From the data we can get a conclusion that there is a rather large discrepancy among learners' use of metacognitive strategies in listening comprehension. In other words, some learners make full use of metacognitive strategies to deal with the listening comprehension problem or question, while some learners neglect the knowledge of metacognitive strategies. From the data and the relevant analysis, we can get a conclusion that students' metacognitive strategies use frequency is relative low, and there is a rather large discrepancy among students ' use of metacognitive strategy on listening comprehension. The reason can be laid on the following factors: At first, the students in Blue Sky College are from different provinces and different senior schools. So their education background is different. Second, most of the countryside high schools do not pay much attention to the listening and speaking. Students in those schools spent little time on listening. 


\subsection{Comparison in Metacognitive Strategy Use between Males and Females}

Table 2. Comparison gender difference in metacognitive strategy use between males and females

\begin{tabular}{cllllll}
\hline MCS & Sex & $\mathrm{N}$ & Mean & $\begin{array}{l}\text { Std. } \\
\text { Deviation }\end{array}$ & $\mathrm{t}$ & Sig, \\
\hline \multirow{2}{*}{ PS } & 1 & 66 & 2.3398 & 0.51888 & -3.198 & 0.002 \\
& 2 & 73 & 2.6184 & 0.50735 & & \\
MS & 1 & 66 & 2.4758 & 0.43148 & -4.018 & 0 \\
& 2 & 73 & 2.826 & 0.57712 & & \\
SES & 1 & 66 & 2.4545 & 0.55512 & -3.157 & 0.002 \\
& 2 & 73 & 2.742 & 0.51822 & & \\
SRS & 1 & 66 & 2.1212 & 0.61275 & -2.978 & 0.003 \\
& 2 & 73 & 2.4315 & 0.61416 & & \\
\hline
\end{tabular}

NOTE:

PS: Planning Strategies MS: Monitoring Strategies SES: Self-evaluation Strategies SRS: Self-regulation 1: Male 2: Female

To make clear whether there is difference between males and females in the metacognitive strategy use during the listening class, an independent samples t-test is used. Table 2 indicates means and standard deviation of metacognitive strategy use between males and females. According to the table above, the means of overall strategies of males are 4.9698 and females are 5.1043. Standard deviations of males is 1.23280 and females are $1.22572(\mathrm{p}=.000<.05)$. It indicates that male students use less metacognitive strategy than female ones and the difference between males and females on listening strategy use is significant.

In the present study, there is significant difference in the use of planning strategies, monitoring strategies, self-evaluation strategies and self-regulation strategies, and the most significant difference is shown in monitoring strategies $(\mathrm{p}=.000<.05)$, The means of monitoring strategy application of males and females are 2.4758 and 2.8260 respectively. The standard deviations are .43148 and .57712 respectively. The possible interpretations for the findings: Although males are doing better in abstract and logical thought, they are not as good as females in self-introspection, insight and thought-control, which are aspects of metacognitive abilities. Females know better than males when referred to reminding themselves of the key information during the listening comprehension.

The second most significant difference is shown in the self-regulation strategies and self-evaluation strategies. The means of self-regulation strategies use of male and female are 2.1212 and 2.4315 . The standard deviations are .61275 and .61416 respectively $(\mathrm{p}=.003<.05)$. The means of self-evaluation strategies application of males and females are 2.4545 and 2.7420 respectively. The standard deviations are .55512 and .51822 respectively $(\mathrm{p}=.002<.05)$. Females are believed as better language learners in foreign language learning. They arrange their learning time reasonable than males student and prefer to reciting lots of language points and model text. Most of researchers admitted that females' gift in language learning is higher than males.

The last one is planning strategies, the means of planning strategies of males and females are 2.3398 and 2.6184 respectively. Standard deviations are .51888 and .50735 respectively $(\mathrm{p}=.002<.05)$. Many previous researches (Green \& Oxford, 1995; Oxford \& Nyikos, 1989) indicate that females employ learning strategies more often than males' students. The main reason for those results lays in the awareness of strategy use. Male students pay more attention to the metacognitive strategy use in their daily study, so they can use them swiftly in listening. For this reason, it is necessary for teachers to foster vocational students' awareness of metacognitive strategy use in listening. Chavez (2001) addressed that second language teachers can strength students' awareness of metacognitive strategy to help either gender to achieve successes in second language listening comprehension. Given males and females an equal chance to learn, individual students' requirements can be quietly accommodated.

\subsection{Comparison in Metacognitive Strategy Use between High Score and Low Score Students}

Data of the listening comprehension test is calculated by SPSS. The total score of the listening test is 15 . Through calculation, the subjects' scores ranged from 2 to 13. Descriptive statistics of Metacognitive Strategies are demonstrated (see table 3) 
Table 3. Descriptive statistics of the listening comprehension test

\begin{tabular}{ccccc}
\hline Total Score & Maximum & Maximum & Range & Mean \\
\hline 15 & 13 & 2 & 11 & 7.07 \\
\hline
\end{tabular}

In the study, the size of the population is 139. The first 38 students (group 1) are taken out as the high score students. The number of low score students is the same as the high score students'. So we take the last 38 students as the low score students. The use of four kind metacognitive strategies by the two groups of students is listed in detail (see table 4)

Table 4. Categories of metacognitive strategy use between low score and high score students

\begin{tabular}{ccccccc}
\hline MCS & Group & $\mathrm{N}$ & Mean & Std. Deviation & $\mathrm{t}$ & Sig. \\
\hline \multirow{2}{*}{ PS } & 1 & 38 & 2.8835 & 0.45158 & \multirow{2}{*}{7.599} & 0 \\
& 2 & 38 & 2.1015 & 0.44549 & & \\
MS & 1 & 38 & 3.1763 & 0.43148 & \multirow{2}{*}{0.653} & 0 \\
& 2 & 38 & 2.2053 & 0.50694 & & \\
SES & 1 & 38 & 3.0395 & 0.52909 & \multirow{2}{*}{6.646} & 0 \\
& 2 & 38 & 2.2544 & 0.50036 & & 0 \\
SRS & 1 & 38 & 2.7303 & 0.67878 & 6.874 & 0 \\
& 2 & 38 & 1.8158 & 0.46019 & & \\
\hline
\end{tabular}

Notes: 1: High score students group 2: Low score students group

Independent sample t-test is used to see whether there is difference between high score students and low score students in the metacognitive strategy use in listening comprehension. According to table 5, the means of overall strategy of high score students is 4.9302, and low score students is 4.7130. Standard deviations are 1.227 and 1.24 respectively $(\mathrm{p}=.000<.05)$. Results indicate that low score students assume lower metacognitive strategy use than high score students and the difference between high score students and low score students on listening strategy use is significant.

In the present study, there is significant difference in the use of planning strategies, monitoring strategies, self-evaluation strategies and self-regulation strategies, and the most significant difference is shown in monitoring strategies. The means of monitoring strategy use of high score students and low score students are 3.1763 and 2.2053 respectively. The standard deviations are .50694 and .35713 respectively $(p=.000<.05)$. There are two reasons: First, in group one, 29 out of 38 students are female, female students have more language talent than male students, they are good at thought-control. So they can get better performance in the listening comprehension test. Second, a positive relationship might exist between metacognitive strategies and listening comprehension ability.

The means of self-evaluation strategies use of high score students and low score students are 3.0395 and 2.2044 respectively. The standard deviations are .52909 and .50036 respectively $(\mathrm{p}=.000<.05)$. The means of self-regulation strategies use of high score students and low score students are 2.7303 and 1.8158 . The standard deviations are .67878 and .46019 respectively $(\mathrm{p}=.000<.05)$. The means of planning strategies of high score students and low score students are 2.8835 and 2.1015 respectively. Standard deviations are .45158 and .44549 respectively $(\mathrm{p}=.000<.05)$. The table shows that the high score students use metacognative strategy more often than the low score students. The reason is that using of metacognative strategy can help students deal with the listening comprehension more effetely. In other words, the more frequently they use the metacognitive strategies, the better performance they can get. 


\subsection{Relationship between Metacognitive Listening Strategy and Listening Comprehension}

4.4.1 Correlations between Listening Comprehension Metacognitive Strategy and English Listening Comprehension

Table 5. Correlations between Listening Comprehension Metacognitive Strategy and English Listening Comprehension

\begin{tabular}{|c|c|c|c|c|}
\hline \multicolumn{3}{|c|}{ Control Variables } & $\mathrm{LC}$ & MS \\
\hline \multirow{4}{*}{ EP } & \multirow{2}{*}{$\mathrm{LC}$} & Correction & 1 & 0.747 \\
\hline & & Significance & . & 0 \\
\hline & \multirow{2}{*}{ MS } & Correction & 0.747 & 1 \\
\hline & & Significance & 0 & . \\
\hline
\end{tabular}

Notes: EP=English proficiency LC=Listening comprehension MS=Metacognitive strategies

As displayed in Table 5, the partial correlation coefficient is .747 and the $p=.000<.05$, which indicates that there is a positive relationship between metacognitive strategies and listening comprehension. In other words, the more proficient the students are, the more frequently they use the metacognitive strategies. Whether the English learners' listening comprehension ability strong or not is quite related to the frequency of the metacognitive strategies they use. In Connolly \& Sluckin's view, the correlation between metacognitive strategies and listening comprehension ability is significantly moderate $(\mathrm{r}=.747, \mathrm{p}<.05)$. The results indicate that it's important for learners to strengthen their listening comprehension ability through mastering metacognitive knowledge.

\subsubsection{Correlation between Four Categories of Strategy and Listening Comprehension}

This part will further explore the detail correlation between the four categories of metacognitive strategies use and listening comprehension ability. Pearson correlation is conducted and all of the results are shown in the Table 6.

Table 6. Pearson Correlation between Four Categories of Metacognitive Strategies Use and Listening Comprehension Test Score

\begin{tabular}{ccccccc}
\hline & & LCTS & PS & MS & SES & SRS \\
\hline LCTS & Pearson Correction & 1 & $.621^{* *}$ & $.690^{* *}$ & $.536^{* *}$ & $.602^{* *}$ \\
& Sig.(2-tailed) & & 0 & 0 & 0 & 0 \\
PS & N & 139 & 139 & 139 & 139 & 139 \\
& Pearson Correction & $.621^{* *}$ & 1 & $.621^{* *}$ & $.562^{* *}$ & $.532^{* *}$ \\
& Sig.(2-tailed) & 0 & & 0 & 0 & 0 \\
MS & $\mathrm{N}$ & 139 & 139 & 139 & 139 & 139 \\
& Pearson Correction & $.690^{* *}$ & $.621^{* *}$ & 1 & $.631^{* *}$ & $.568^{* *}$ \\
& Sig.(2-tailed) & 0 & 0 & & 0 & 0 \\
SES & $\mathrm{N}$ & 139 & 139 & 139 & 139 & 139 \\
& Pearson Correction & $.536^{* *}$ & $.562^{* *}$ & $.631^{* *}$ & 1 & $.594^{* *}$ \\
& Sig.(2-tailed) & 0 & 0 & 0 & & 0 \\
SRS & $\mathrm{N}$ & 139 & 139 & 139 & 139 & 139 \\
& Pearson Correction & $.602^{* *}$ & $.532^{* *}$ & $.568^{* *}$ & $.594^{* *}$ & 1 \\
& Sig.(2-tailed) & 0 & 0 & 0 & 0 & \\
& $\mathrm{~N}$ & 139 & 139 & 139 & 139 & 139 \\
& $* *$ Correlation is significant at the 0.01 level (2-tailed). & \\
\hline
\end{tabular}

Notes: LCTS: Listening comprehension test score

As displayed in Table 6, the relationship between metacognitive strategy knowledge and listening comprehension ability is quite significant. The most obvious correlation is between monitoring strategies and listening comprehension test $\operatorname{score}(\mathrm{r}=.690 \mathrm{p}=.000)$, which indicates that students can select the right 
metacognitive strategies to complete the listening comprehension tasks. When they do the listening comprehension tests, they try their best to concentrate on the material, skim the fuzz words and go on with the listening comprehension. They can also adjust the metacognitive strategies according to the difficulty of the listening comprehension task. For example, the students involve their experience, which is similar to the listening material, into the comprehension while the listening material has too many new words to understand. All in all, students have mastered quite a lot of metacognitive listening strategies for they have received almost 7 years English classroom instruction. However, they can't use the strategies properly for lacking of metacognitive strategies knowledge. Therefore, it's necessary for students to grasp the monitoring strategies knowledge to improve their listening comprehension ability.

The other three categories of metacognitive strategies also have significant correlations with the listening comprehension ability. The Pearson correlation coefficient is .621 between planning strategies and listening comprehension test score and $\mathrm{P}=.000<.05$. The Pearson correlation coefficient is .536 between self-evaluation strategies and listening comprehension test score and $\mathrm{P}=.000<.05$. The Pearson correlation coefficient is .602 between self-regulation strategies and listening comprehension test score and $\mathrm{P}=.000<.05$. Compared the four strategies, the Pearson correlation coefficient between self-evaluation strategies and listening comprehension test score is the lowest. That does not mean that self-evaluation strategies are useless in the listening comprehension. On the contrary, it indicates that the students' self-evaluation strategies knowledge is not enough in some extent. The main reason is that almost all the students in their high schools didn't receive relevant training of metacognitive strategy. So it's necessary for vocational college English teachers to teach students metacognitive strategy knowledge.

\subsection{Discussion of the Interview}

Question 1: During the English learning process, have you met difficulties? What kind of difficulties and how did you get over it?

Student One: Of course, I often meet some troubles in my study. My listening comprehension and writing ability is very week, especially the listening comprehension. I don't know how to improve it. Now, I try my best to listen to the English broadcast, read English novels, English magazine and recite a lot of model articles.

Student Two: Many, it is very hard for me to understand English. Such as reading comprehension, listening comprehension, grammar. During the listening comprehension, I even can not catch one word. I don't kwon how to deal with those problems, so I set them aside and don't care about it.

Student Three: Yes, my listening comprehension ability is very week and I do not know how to improve it.

As for most of the low level students, they often met difficulties in the English listening comprehension, just like Student Two and Three. Among those difficulties, how to understand the meaning of some words is the most difficult one. There are mainly two reasons: the first one is that their vocabulary is not large enough, and this is the direct reason; the second reason is that they can recognize the words when they see the word, but when the words appear in the form of voice in the listening task they can't understand them properly. For many of them don't know how to pronounce the words in a correct way. Grammar is another difficult for them, in the listening comprehension task, they can get most of the words meaning sometimes, however, for the lacking of necessary knowledge of grammar, they failed to understand the meaning of the whole passage even the sentence, especially when the background is unfamiliar to them. When they meet those questions, they can do nothing but guessing the answer when the listening comprehension comes to an end.

In terms of the high level students, they sometimes also met the similar difficulties as the low students. For example, the difficult words appear in the listening comprehension and the speech speed is too quick and so on, just like student one. But they try their best to deal with those difficulties. Most of the time, they skim the point which is not clear and concentrate on the next one. And when the whole listening comprehension is completed, they come back to pin down the answer according to their experience. This is the big difference between the high level students and low level students. Besides, they read lots of English materials (English novels, English magazine, China Daily and so on) to enlarge their vocabulary or recite the new words directly.

Question 2: Do you often review the key points and finish the task according to your experience?

Student One: Yes, I often try to catch the key words and information during the listening comprehension. Then I will judge the context according to the information. Of course, before the listening comprehension, I would like to go through the listening comprehension material and mark some key words. 
Student Two: No, I can't catch any word at all, so I don't care about it.

According to the interview, there are three kinds of answers to this question:

(1) Before the listening comprehension, they just wait and review nothing of the key points. When the listening comprehension finished, there is nothing left in their mind. Therefore, it is impossible to complete the tasks according to their experience. This phenomenon mostly occurs in the low level students.

(2) Reviewing and marking the key points before the listening comprehension if there is enough time to do that. But sometimes it is hard to link the listening comprehension with their personal experience for the time or experience is limited. According to some students' interview, they have no time to finish the tasks according to their experience for the speech speed is fast and have to concentrate on the coming task.

(3) As for the high level students, they review and mark the key points as quickly as possible before the listening comprehension. Sometimes they add their personal experience into listening comprehension unconsciously. They don't think this process needs any time because they had read lots of similar English materials.

All in all, experience is important to vocational college students during the listening comprehension test. As ku (1998) pointed out that the more experience the learners have, the more frequently their use the learning strategies.

Question 3: Do you often pay attention to the special details when you listen to the message? What are the details?

Student One: I don't pay much attention to the details during the listening process, but I will try my best to get the general ideal of the material. As far as detail is concerned, I often pay attention to the time and place that appeared in the material. Before the listening, I will read the questions and answers so as to make a reasonable choice.

Student Two: Yes, I often try my best to get as much information as I can, after that I can use the information I get to judge the general idea of the material.

Student Three: I can't catch the meaning of the material, so I choose the answer by chance.

From students answers, we can get a conclusion: They are five factors the high level students usually pay attention to: subjects, which refer to how many people concerned in the listening comprehension and the relationship between them; time, which means when did the event happened; event, which means what happened; place, which means where did the event happened; process and result. Beside those factors, they also pay attention to the figures for sometimes the simple calculation is needed in the listening comprehension. And most of the low level students didn't own that ability.

Question 4: Which is the best way to improve your listening comprehension ability in you opinion?

Student One: For me, the most efficient way is practice listening. As we know, practice makes perfect. And reading also is very helpful to my listening comprehension. It makes me understand the listening comprehension better.

Student Two: I think watching English film and listening to English music is a good way to improve one's listening comprehension ability.

Student Three: Just listen to the material, again and again, until you are familiar with it.

Different students have different opinions on that question. listening to the radio broadcasting, listening to others when they are speaking English, listening to the selected tapes, listening to his/her teacher when the teacher is speaking English and so on. According to the interview, half of the interviewees select watching English movies as their ideal way to improve their listening comprehension ability. It is interesting and fun. As we know, interest is the best teacher in any learning process. Watching English movies is a very effective way to practice one's English listening ability. On one hand one can enjoy the attractive plot and the story while watching a good movie, on the other hand, he can and would try easily to focus his mind and attention to all the words spoken by the heroes and heroines in the movie, so as to understand what they are talking about and to appreciate the story better. What is more, the words spoken in a film are more likely to be what one say in daily life, natural and true to reality, that means one can learn a lot about how to express oneself when he or she has a desire to communicate with other in an idiomatic and native way. This can be the supplementary benefits one can obtain when practicing his or her listening ability. 
Question 5: How to practice your listening comprehension? Why?

Student One: I often listen to the materials that come from the textbook. There are three reasons for that. First, it is easy to get the material; second, it's easy to review the material and the third reason is that listening comprehension is easy to check the answer.

Student Two: I hardly practice my listening comprehension, so don't know how to improve my listening comprehension ability.

The difference between the low level and high level students is very clear. Quite few of the low level students show they couldn't apply proper way to practice their listening comprehension. Because there is little improvement in their listening comprehension ability no matter what way they used. However, most of the high level students tend to practice their listening comprehension through watching English movies and listening to the English radios. During that process, they often try to catch the key words and phrases or imitate the actors' saying, sometimes even recite the classical dialogue of the movie. It is interesting and easy to get the ability of language sensitivity. In a word, the low students maybe know the way to practice their listening comprehension, but they did not use the method in a correct way. Therefore, they failed to improve their listening comprehension.

From the five questions and results listed above, the reasons for the failure of low level students and the success for the high level students can be found. As for the low level students, they couldn't use the metacognitive strategies properly and lack the knowledge of metacognitive strategies. The desire to practice their listening comprehension is low. They couldn't get the general idea of the listening material but just paid attention to the meaning of phrases or signal words. The low students' learning efficiency is lower than the high level students. And the efficiency here can be explained into some strategies. To sum up, ones' success in listening comprehension is due to the metacognitive strategies use in a proper way.

\section{Conclusions}

Based on the above empirical research findings, we have claimed that ineffective students do suffer from lack of some kind of knowledge about metacognitive strategies. Therefore, enhancing learners' metacognitive strategy should be necessary in the vocational college English teaching and learning. Teachers should take measures to arouse students' interest in English and foster their metacognitive strategy knowledge. The following are some pedagogical implications for college students' English teaching and learning.

Firstly, knowledge of the metacognitive strategy plays a crucial role in listening comprehension. For vocational college students, metacognitive strategy knowledge seems senseless if they know nothing about it. So only when learners get such knowledge can they check what they know about listening comprehension and what they do not know so that learners realize their own problems and gain confidence. With the metacognitive strategy knowledge, they can carry out plans as a training goal smoothly instead of listening aimlessly. Schraw (2001) addressed that it is activation of metacognitive strategy knowledge that contributes to the successful comprehension and task-relevant strategies use.

Secondly, autonomous and self-regulated learning need learners' metacognitive strategy knowledge. Teacher should try their best to help college students develop a more reflective and self-directed approach to learning their new language. Teachers should also guide college students to improve and expand their knowledge about learning so that they may become autonomous in their approach to the learning of their new language. Flavell (1979) addressed that knowledge about metacognitive strategies is the basis for learning process. With the metacognitive strategy knowledge, they can arrange their learning process in a smooth way and handle all kinds of learning problem easily. Especially in the listening comprehension input, they will monitor the process of listening and choose the right strategy when they face different comprehension task.

\section{References}

Anderson, A., \& T. Lynch. (1988). Listening. Oxford: Oxford College Press.

Anderson, J. R. (1985). Cognitive Psychology and its Implications. New York: W. H. Freeman.

Anderson, NJ. (2013). Meta-cognitive reading strategies increase L2 performance. The Language Teacher, (27), 20-22.

Anderson. (2002). Principles of language learning and teaching. Beijing: Beijing Foreign Language Teaching and Research Press.

Barker, L. (1971). Listening Behavior. Englewood Cliff, NJ: Prentice Hall. 
Boulton, A. \& T. Cobb. (2017). Corpus use in language learning: A meta-analysis. Language Learning, 2017(2), 348-393. https://doi.org/10.1111/lang.12224

Bozorgian, H. \& E. Alamdari. (2018). Multimedia listening comprehension: Metacognitive instruction or metacognitive instruction through dialogic interaction. RECALL, 2018(1), 131-152. https://doi.org/10.1017/S0958344016000240

Brown, A. L. (1978). Knowing when, where, and how to remember: metacognition. In R. Glaser (ed.), Advances in Instructional New York: Halsted Press. A problem of Psychology. New York: Halsted Press.

Brown, A. L., \& Day, J. D. (1983). Macrorules for summarizing texts: The development of expertise. Journal of Memory and Language, 22, 1-14. https://doi.org/10.1016/S0022-5371(83)80002-4

Brown, B. (1987). Metacognition, Executive Control, Self-regulation, and other more Motivation Mechanisms. In R E. Weinert \& R. H. Kluwe (eds.): Metacognition, and Understanding. Hillsdale, New Jersey: Lawrence Erlbaun Associates, 65-116.

Brown, G. (1977). Listening to Spoken English. London: Longman.

Brown, G. (1993). Listening to Spoken English. Longman

Carrel, P. L. (1989). Metacognitive awareness and second language Reading. The Modern Language Journal, 73, 121-134. https://doi.org/10.1111/j.1540-4781.1989.tb02534.x

Christine, C. M. Goh. (2002). Exploring listening comprehension tactics and their interaction patterns. System, 30, 185-206. https://doi.org/10.1016/S0346-251X(02)00004-0

Cohen, A. (2000). Strategies in learning and using a second language. Beijing: Foreign Language Teaching and Research Press.

Cohen, A. D. (1990). Language Learning: Insights for Learners, Teachers, and Researchers. New York: Newbury House.

Cohen, A.D. (1998). Strategies in learning and using a second language. Addison Wesley Longman Limited.

Garner, R. (1988). Verbal report data on cognitive and metacognitive strategies. In C.E. Weinstein, E.T. Goets, \& P.A. Alexander (Eds.), Learning and Study Strategies: Issues in Assessment, Instruction, and Evaluation (pp. 135-158). San Diego: Academic Press. https://doi.org/10.1016/B978-0-12-742460-6.50011-6

Goh, C. (1997). Metacognitive awareness and second language listeners. ELT Journal, 51, 361-369. https://doi.org/10.1093/elt/51.4.361

Goh, C., \& Taib, Y (2006). Metacognitive instruction in listening for young learners. ELT Journal, 60(3), 222-232. https://doi.org/10.1093/elt/cc1002

Green, J. M. \& Oxford, R. L. (1995). A closer look at learning strategies, L2 proficiency, and gender. TESOL Quarterly, 29(2), 261-297. https://doi.org/10.2307/3587625

Horwitz, E. K. (1987). Surveying students' beliefs about language learning. In A.L. Wenden \& J. Rubin (Eds.), Learner strategies in language learning (pp. 119-129). Englewood Cliffs, NJ: Pretence-Hall.

Kelly, P (1991). Lexical ignorance: The main obstacle to listening comprehension with advanced foreign language learners. IRAL, 29, 125-149.

Kenneth, C. (1976). Developing Second Language Skills: Theory to Practice. Houghton Miffilin Company.

Kobayashi, A. (2018). Investigating the effects of metacognitive instruction in listening for EFL learners. The Journal of Asia TEFL, 2018(2), 310-328. https://doi.org/10.18823/asiatefl.2018.15.2.4.310

Krashen S.D. (1985). The Input Hypothesis: Issues and Implications. London: Longman.

Ku, P Y (1998). Strategies associated with listening comprehension of EFL students. Shanghai International Studies College, Shanghai.

Mendelsohn, D. J. (1994). Learning to Listening. San Diego, CA: Dominie Press.

O’Malley, J. M., A. U. Chamot, G. (1985). Stewner-Manzanares, R. P. Russo \& L. Kupper. Learning strategy applications with students of English as a second language TESOL Quarterly 19/3, 557-584. https://doi.org/10.2307/3586278

Oxford, R. L., \& Nikons, M. (1989). Variables affecting choice of language learning strategies by college students. Modern Language Journal, 73, 291-300. https://doi.org/10.1111/j.1540-4781.1989.tb06367.x 
Paris, G S., \& Wino grad, P (1990). How metacognition can academic learning and instruction. In B.F. Jones \& L. Idol (Eds.), Dimensions of Thinking and Cognitive Instruction (pp. 15-51). Hillsdale, NJ: Lawrence Erlbaum.

Rahimi, M. \& Katal, M. (2012). The role of metacognitive listening strategies awareness and Podcast-use readiness in using podcasting for learning English as a foreign language. Computers in Behavior, (4), 1153-1161. https://doi.org/10.1016/j.chb.2012.01.025

Rahimi, M.and Abedi, S. (2014). The Relationship between Self-efficacy and Metacognitive Awareness of Listening Strategies. Procedia-Social and Behavioral Sciences, 1454-1460. https://doi.org/10.1016/j.sbspro.2014.03.565

Rivers, W. M. \& Temperly, M. S. (1978). A Practical Guide to the Teaching of English. New York: CUP.

Rost, M. (2002). Teaching and Researching Listening. London, UK: Longman, 35.

Rubin, J. (1994). A review of second language listening comprehension Research. The Modern Language Journal, 78, 199-221. https://doi.org/10.1111/j.1540-4781.1994.tb02034.x

Skehan, E. (1989). Language Learning Strategies. London: Edward Arnold Limited.

$\mathrm{Su}$, M. (2003). An investigation of Chinese grade 5-6 students' EFL language learning strategies and language learning experience. The Journal of Educational Science, 3(1), 173-176.

Teng, H. C. (1996). Effects of cultural schemata and visual cues on Chinese students' EFL listening comprehension. Papers from the eleventh conference on English teaching and learning in the Republic of China. Beijing.

Thomas, L. T., \& T.R. (1994). Levine, Disentangling Listening and Verbal Recall: Related but Separate. https://doi.org/10.1111/j.1468-2958.1994.tb00342.x

Wen Qiufang. (1993). Advanced level English learning in China: The relationship of modifiable learner variables to learning outcomes. Hong Kong College: Unpublished doctoral thesis.

Zhang Fangfang. (2016). The effect on the Math Reading Ability of Senior High School Students with Different cognitive styles. Shang Hai: Shanghai Normal University.

\section{Copyrights}

Copyright for this article is retained by the author(s), with first publication rights granted to the journal.

This is an open-access article distributed under the terms and conditions of the Creative Commons Attribution license (http://creativecommons.org/licenses/by/4.0/). 